\title{
Front Matter: Volume 10636
}

, "Front Matter: Volume 10636," Proc. SPIE 10636, Laser Radar Technology and Applications XXIII, 1063601 (11 July 2018); doi: 10.1117/12.2500509

SPIE. Event: SPIE Defense + Security, 2018, Orlando, FL, United States 


\section{PROCEEDINGS OF SPIE}

\section{Laser Radar Technology and Applications XXIII}

Monte D. Turner

Gary W. Kamerman

Editors

17-18 April 2018

Orlando, Florida, United States

Sponsored and Published by

SPIE 
The papers in this volume were part of the technical conference cited on the cover and title page. Papers were selected and subject to review by the editors and conference program committee. Some conference presentations may not be available for publication. Additional papers and presentation recordings may be available online in the SPIE Digital Library at SPIEDigitalLibrary.org.

The papers reflect the work and thoughts of the authors and are published herein as submitted. The publisher is not responsible for the validity of the information or for any outcomes resulting from reliance thereon.

Please use the following format to cite material from these proceedings:

Author(s), "Title of Paper," in Laser Radar Technology and Applications XXIII, edited by Monte D. Turner, Gary W. Kamerman, Proceedings of SPIE Vol. 10636 (SPIE, Bellingham, WA, 2018) Seven-digit Article CID Number.

ISSN: 0277-786X

ISSN: 1996-756X (electronic)

ISBN: 9781510617834

ISBN: 9781510617841 (electronic)

Published by

SPIE

P.O. Box 10, Bellingham, Washington 98227-0010 USA

Telephone +1 3606763290 (Pacific Time) · Fax +1 3606471445

SPIE.org

Copyright (C) 2018, Society of Photo-Optical Instrumentation Engineers.

Copying of material in this book for internal or personal use, or for the internal or personal use of specific clients, beyond the fair use provisions granted by the U.S. Copyright Law is authorized by SPIE subject to payment of copying fees. The Transactional Reporting Service base fee for this volume is $\$ 18.00$ per article (or portion thereof), which should be paid directly to the Copyright Clearance Center (CCC), 222 Rosewood Drive, Danvers, MA 01923. Payment may also be made electronically through CCC Online at copyright.com. Other copying for republication, resale, advertising or promotion, or any form of systematic or multiple reproduction of any material in this book is prohibited except with permission in writing from the publisher. The CCC fee code is 0277$786 \mathrm{X} / 18 / \$ 18.00$.

Printed in the United States of America.

Publication of record for individual papers is online in the SPIE Digital Library.

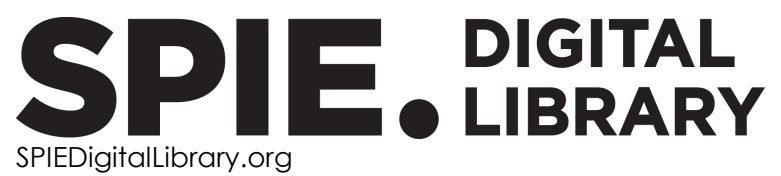

Paper Numbering: Proceedings of SPIE follow an e-First publication model. A unique citation identifier (CID) number is assigned to each article at the time of publication. Utilization of CIDs allows articles to be fully citable as soon as they are published online, and connects the same identifier to all online and print versions of the publication. SPIE uses a seven-digit CID article numbering system structured as follows:

- The first five digits correspond to the SPIE volume number.

- The last two digits indicate publication order within the volume using a Base 36 numbering system employing both numerals and letters. These two-number sets start with $00,01,02,03,04$, 05, 06, 07, 08, 09, 0A, OB ... 0Z, followed by 10-1Z, 20-2Z, etc. The CID Number appears on each page of the manuscript. 


\title{
Contents
}

\author{
$\checkmark \quad$ Authors \\ vii Conference Committee
}

\section{SESSION $1 \quad$ AIRBORNE TARGET DETECTION AND CHARACTERIZATION}

1063602 Laser profiling for airborne target classification [10636-1]

1063603 Identifying drone-related security risks by a laser vibrometer-based payload identification system [10636-2]

1063604 Aerial and surface security applications using lidar [10636-3]

1063605 Potential of lidar sensors for the detection of UAVs [10636-4]

\section{SESSION 2 LASER RADAR ENABLING TECHNOLOGIES AND TECHNIQUES I}

1063606 An optical scanner based on beam switching method fabricated on silicon photonics circuit [10636-5]

1063607 Backward ray tracing for the stray light analysis of the modulated optical system [10636-6]

1063608 Dark non-uniformity correction and characterization of a 3D flash lidar camera [10636-7]

\section{SESSION $3 \quad$ LASER RADAR ENABLING TECHNOLOGIES AND TECHNIQUES II}

1063609 Atmospheric effects and impact on target classification for Synthetic Aperture Ladar (SAL) imagery [10636-8]

10636 OC Temporally multiplexed multispectral ladar with Raman-based waveforms [10636-30]

\section{SESSION 4 COMPACT LASER RADAR SYSTEMS}

10636 OE MEMS-scanned ladar for small unmanned air vehicles [10636-12]

10636 OF Ultra-compact solid state laser [10636-13] 
10636 OG A compact 3D lidar based on an electrothermal two-axis MEMS scanner for small UAV [10636-14]

\section{SESSION $5 \quad$ ATMOSPHERIC LIDAR APPLICATIONS}

$10636 \mathrm{Ol} \quad$ A Langley extrapolation technique applied to atmospheric aerosol lidars [10636-16]

10636 OJ Lidar detection of small aerosol size distribution [10636-17]

10636 OK Compact lidar for continuous monitoring of atmospheric extinction [10636-18]

$10636 \mathrm{OL} \quad$ Using a bistatic camera lidar to profile aerosols influenced by a local source of pollution [10636-19]

\section{SESSION 6 ADVANCED DATA PROCESSING AND EXPLOITATION I}

10636 OM Noisy lidar point clouds: impact on information extraction in high-precision lidar surveying [10636-20]

10636 ON Total propagated uncertainty for coastal zone mapping and imaging lidar (CZMIL) [10636-21]

\section{SESSION 7 ADVANCED DATA PROCESSING AND EXPLOITATION II}

10636 OP Large-scale public lidar and satellite image data set for urban semantic labeling [10636-23]

$106360 Q \quad$ Super-resolution textured digital surface model formation using aerial texel images taken from a low-cost, small unmanned aerial system [10636-24]

SESSION 8 SPACE-BASED LASER RADAR APPLICATIONS

10636 OS Space-based photon-counting laser altimetry for global applications [10636-26]

10636 OT Component-level selection and qualification for the Global Ecosystem Dynamics Investigation (GEDI) laser altimeter transmitter [10636-27]

10636 OU Qualification of the solid state laser systems for the GEDI altimeter mission [10636-28]

10636 OV A mission-enabling UV laser for mass spectrometry (UVMS) with continuously selectable output for in-situ planetary exploration [10636-29] 


\section{Authors}

Numbers in the index correspond to the last two digits of the seven-digit citation identifier (CID) article numbering system used in Proceedings of SPIE. The first five digits reflect the volume number. Base 36 numbering is employed for the last two digits and indicates the order of articles within the volume. Numbers start with 00, 01, 02, 03, 04, 05, 06, 07, 08, 09, OA, OB...0Z, followed by 10-12, 20-2Z, etc.

\author{
Allard, Lars, 02 \\ Almes, Scott, OP \\ Arens, Michael, 05 \\ Arevalo, Ricardo, OV \\ Ausley, Luke, OC \\ Bai, Yunkai, OG \\ Baranova, Nadezhda, OF \\ Barnes, John E., OL \\ Barnes, Lawrence J., 09 \\ Berglund, Folke, 02 \\ Bierig, Andreas, 03 \\ Blalock, Gordon, OU \\ Borgmann, Björn, 05 \\ Bosch, Marc, OP \\ Bradley, C., 08 \\ Bridgewater, Mauricio, OL \\ Brown, Myron, OP \\ Budge, Scott E., $O Q$ \\ Butt, Jalal, OL \\ Chiragh, Furqan L., OT, OU \\ Church, Philip, 04 \\ Clarke, Greg B., OU, OV \\ Coyle, D. Barry, OT, OU, OV \\ Dammann, John F., OE \\ Duong, Hieu, ON \\ Feygels, Viktor, ON \\ Foster, Kevin, OP \\ Frese, Erich A., OT, OU \\ Friess, Peter, ON \\ Gimmestad, Gary, OI \\ Giza, Mark M., OE \\ Goldberg, Hirsh, OP \\ Goodwin, Joseph A. K., OK \\ Grebe, Christopher, 04 \\ Hagstrom, Shea, OP \\ Hallen, Hans D., OJ \\ Hammer, Marcus, 05 \\ Hebel, Marcus, 05 \\ Hersh, Michael, OU \\ Hong, Jinsuk, 07 \\ Ichikawa, Tadashi, 06 \\ Inove, Daisuke, 06 \\ Ismail, Mohamed A. A., 03 \\ Johnston, Chase, Ol \\ Kabir, Amin S., OL \\ Kawasaki, Akari, 06 \\ Kay, Richard B., OU \\ Keaffaber, Brett L., 09 \\ Keyser, Christian, OC
}

Khatiwada, Bikalpa, $0 Q$

Kim, Sug-Whan, 07

Kirchner, Cindy, OU

Koh, Hae Seog, 07

Kopilevich, Yuri, ON

Koppal, Sanjeev, OG

Lander, Juan, OU

Laurenzis, Martin, 05

Lee, A., 08

Leichtman, Andrea, OP

Magruder, Lori A., OS

Martin, Richard, OC

Matheson, Justin, 04

McManamon, P. F., 08

Miller, D., 08

Minelli, Robert J., OK

Morey, Peter, OU

Mule, Pete, OU

Nevenschwander, Amy L., OS

Owens, Brett, 04

Park, Eric D., OF

Pati, Bhabana, OF

Pfennigbaver, M., OM

Philbrick, C. Russell, OJ

Poulios, Demetrios, OU, OV

Ramnath, Vinod, ON

Rawlins, W. Terry, OK

Reinhardt, A. D., 08

Rigling, Brian D., 09

Ross, Jacob W., 09

Ruff, William C., OE

Rustowicz, Rose M., 09

Sharma, N. C., OL

Shin, Jung-Hwan, 07

Smith, Kevin, OU

Sonnenfroh, David M., OK

Stainsby, Aaron, OG

Stann, Barry L., OE

Steinvall, Ove, 02

Stewart, John, ol

Strassle, Stephan, OG

Stysley, Paul R., OT, OU, OV

Switzer, Robert, OT

Thomas, Joe, 0T

Tulldahl, Michael, 02

Ullrich, A., OM

Valenta, Christopher R., 01

Vasilyev, Aleksey A., OT

Wang, Dingkang, OG 
Wang, Sean, OP

Washington, Kristen, OU

Watson, Edward A., 09

Xie, Huikai, OG

Yamashita, Tatsuya, 06

Proc. of SPIE Vol. 10636 1063601-6

Downloaded From: https://www.spiedigitallibrary.org/conference-proceedings-of-spie on 26 Apr 2023 Terms of Use: https://www.spiedigitallibrary.org/terms-of-use 


\title{
Conference Committee
}

\author{
Symposium Chairs
}

Arthur A. Morrish, Raytheon Space and Airborne Systems

(United States)

Ruth L. Moser, Air Force Research Laboratory (United States)

Conference Chairs

Monte D. Turner, Air Force Research Laboratory (United States)

Gary W. Kamerman, FastMetrix, Inc. (United States)

Conference Program Committee

Philip Gatt, Lockheed Martin Coherent Technologies (United States)

Dominique Hamoir, ONERA (France)

Richard M. Heinrichs, MIT Lincoln Labs. (United States)

Thomas J. Karr, Defense Advanced Research Projects Agency

(United States)

Lori A. Magruder, Applied Research Laboratories, The University of Texas at Austin (United States)

Vasyl Molebny, National Taras Shevchenko University of Kyiv (Ukraine)

C. Russell Philbrick, North Carolina State University (United States)

Upendra N. Singh, NASA Langley Research Center (United States)

Ove Steinvall, FOI-Swedish Defence Research Agency (Sweden)

Grady H. Tuell, 3D Ideas, LLC (United States)

Douglas G. Youmans, Parsons Corporation (United States)

\section{Session Chairs}

1 Airborne Target Detection and Characterization

Gary W. Kamerman, FastMetrix, Inc. (United States)

2 Laser Radar Enabling Technologies and Techniques I

Lori A. Magruder, Applied Research Laboratories, The University of Texas at Austin (United States)

3 Laser Radar Enabling Technologies and Techniques II

Lori A. Magruder, Applied Research Laboratories, The University of Texas at Austin (United States)

4 Compact Laser Radar Systems

Monte D. Turner, Air Force Research Laboratory (United States) 
5 Atmospheric Lidar Applications

Ove Steinvall, FOI-Swedish Defence Research Agency (Sweden)

6 Advanced Data Processing and Exploitation I

Monte D. Turner, Air Force Research Laboratory (United States)

$7 \quad$ Advanced Data Processing and Exploitation II

Vasyl Molebny, Akademiya Tehnologichnih Sciences of Ukraine (Ukraine)

8 Space-based Laser Radar Applications

Richard M. Heinrichs, Defense Advanced Research Projects Agency (United States) 